\title{
Quantifying RNA and DNA in planktonic organisms with SYBR Green II and nucleases. Part B. Quantification in natural samples*
}

\author{
ELISA BERDALET, CRISTINA ROLDÁN and M. PILAR OLIVAR \\ Institut de Ciències del Mar (CMIMA, CSIC). Passeig Marítim 37-49, 08003 Barcelona, Catalunya, Spain. \\ E-mail: berdalet@icm.csic.es
}

\begin{abstract}
SUMMARY: Extraction procedures for RNA and DNA in crude extracts of natural microplankton samples are developed. The methodology is compatible with the fluorometric assay of RNA and DNA developed by Berdalet et al. (2005). Mechanical cell disruption using a manual tissue grinder is combined with chemical extraction using $0.5 \%$ sarcosine and $0.5 \mathrm{mM}$ EDTA in $5 \mathrm{mM}$ Tris, $\mathrm{pH}$ 8.0, to release the nucleic acid. The new extraction and assay procedure is used to estimate the RNA/DNA ratios of fish larvae and natural microplankton communities maintained in the laboratory under different nutritional conditions. In the two experiments, the RNA/DNA ratios were related to the nutrient availability of the organisms. The level of sensitivity of the method is experimentally set at $c a .40 \mathrm{ng}$ of RNA and $10 \mathrm{ng}$ DNA in the $1 \mathrm{ml}$ assay, which corresponds to a minimum biomass requirement of $c a .400 \mathrm{ng} \mathrm{ml}^{-1}$ protein or $3 \mu \mathrm{g} \mathrm{ml}^{-1}$ dry weight. The precision, estimated at different steps of the procedure, had an overall coefficient of variation of $\leq 10 \%$. The new approach provides RNA/DNA ratios comparable with those obtained with ethidium bromide.
\end{abstract}

Key words: SYBR Green II, DNase, RNase, sarcosine, RNA/DNA ratios, plankton.

RESUMEN: CUANTIFICACIÓN DE ARN Y ADN IN ORGANISMOS PLANCTÓNICOS MARINOS MEDIANTE SYBR GREEN II Y NUCLEASES. PARTE B. CUANTIFICACIÓN EN MUESTRAS NATURALES. - En este trabajo se han desarrollado los protocolos de extracción de ARN y ADN en extractos no purificados de muestras naturales de microplancton. La metodología es compatible con el ensayo fluorimétrico para ARN y ADN desarrollado por Berdalet et al. (2005). La extracción de los ácidos nucleicos se realiza combinando una rotura celular mecánica (mediante un homogeneizador manual de tejidos) con una extracción química (con $0.5 \%$ de sarcosina y $0.5 \mathrm{mM}$ EDTA en tampón Tris $5 \mathrm{mM}$ a pH 8). Este nuevo procedimiento de extracción y ensayo se usó para estimar los cocientes ARN/ADN en larvas de peces y comunidades naturales de microplancton mantenidos en el laboratorio bajo diferentes condiciones nutricionales. En los dos experimentos los cocientes ARN/ADN estuvieron relacionados con los nutrientes disponibles para los organismos. El nivel de sensibilidad del método fue establecido experimentalmente a aproximadamente $40 \mathrm{ng}$ de ARN y $10 \mathrm{ng}$ de DNA en ensayos de $1 \mathrm{ml}$, lo que corresponde a un requerimiento mínimo de biomasa de aproximadamente $400 \mathrm{ng} \mathrm{ml}^{-1}$ de proteína o $3 \mu \mathrm{g} \mathrm{ml}^{-1}$ de peso seco. La precisión, estimada en distintos pasos del método, tuvo un coeficiente de variación global del 10\%. Esta nueva aproximación proporciona cocientes ARN/ADN comparables a las obtenidas con bromuro de etidio.

Palabras clave: SYBR Green II, nucleasas, sarcosina, cociente ARN/ADN, plancton.

\section{INTRODUCTION}

Since the RNA/DNA ratio was first proposed 35 years ago as a biochemical indicator of the physio-

*Received July 17, 2003. Accepted January 10, 2005. logical and nutritional state of organisms in their natural environment (Holm-Hansen et al., 1968) it has been continuously explored (Sutcliffe, 1970; Regnault and Luquet, 1974; Bulow, 1987; Arin et al., 1999). However, some authors have noted that RNA/DNA in young fish (e.g. Mathers et al., 1994; 
Suthers, 1996; Bergeron, 1997) was not a reliable predictor of the variability in physiological, nutritional or environmental conditions. Analytical sensitivity, sampling and extraction problems as well as problems in experimental design were suspected causes. Berdalet et al. (2005) demonstrate the sensitivity of the fluorometric methods to subtle procedural differences and explain the analytical improvements in measuring RNA and DNA with the nucleases and the SYBR Green II based fluorometric assay. The next step was to establish an effective extraction procedure compatible with the use of this protocol. This is described here.

Our laboratory had been measuring RNA and DNA of microplankton or copepod samples collected on GF/F glass fibre filters (Berdalet and Dortch, 1991; Fara et al., 1996; Saiz et al., 1998). Extraction was conducted by simply grinding the filters in a Tris buffer. However, we investigated other ways to improve the nucleic acid extraction. First, we tested the procedure described by Clemmesen (1993) that had been adapted from Molecular Biology protocols for obtaining purified nucleic acids extracts from fish larvae. The methodology used ethidium bromide as the fluorochrome, and SDS, EDTA, chloroform, phenol and isoamylalcohol that were subsequently removed by washing. Although the extraction was efficient, the estimations of RNA and DNA with the SYBR Green II and nucleases methodology were highly variable. This variability was traced to interference with the fluorescent response of SYBR Green II to the GF/F glass fibre filters, and to low biomass. Consequently, we rejected this procedure.

Second, we considered another extraction method for fish larvae (Canino and Caldarone, 1995), in which organisms are mechanically ground in distilled water and homogenates are extracted with $1 \%$ STEB buffer (i.e. $1 \%$ sarcosine, $5.0 \mathrm{mM}$ Tris $\cdot \mathrm{HCl}, 0.5 \mathrm{mM}$ EDTA, $\mathrm{pH}$ 7.5) for $60 \mathrm{~min}$ at room temperature (RT). Extraction is aided by 15 $\mathrm{sec}$ of vortex mixing after the first $30 \mathrm{~min}$. Canino and Caldarone (1995) noted that because the detergent, sarcosine, interferes with ethidium bromide at final concentrations in the assay above $0.012 \%$, it was necessary to suitably dilute the homogenate in Tris buffer. Here we show how we combined this extraction approach with the SYBR Green II and nuclease assays to improve the extraction. With this extraction method we tested the whole protocol (extraction plus assay) in quantifying RNA/DNA ratios in natural plankton samples growing under controlled nutritional conditions. The precision of the whole protocol and its comparison with future studies and with the literature based on ethidium bromide was also studied.

\section{MATERIALS AND METHODS}

\section{(A) General reagents and procedures}

\section{Reagents and solutions}

Detailed information including commercial nomenclature for all chemicals and preparation protocols for the working solutions (i.e. nucleic acid standards, nucleases and SYBR Green II) is found in the accompanying paper (Berdalet et al., 2005: Section A). However, to aid the reader here, note that in descriptions and discussions of the RNA and DNA standards, RNA-Y is RNA from baker yeast, rRNA$\mathrm{L}$ is ribosomal RNA from calf liver, DNA-T is DNA from calf thymus and uDNA-T is ultrapure, genomic DNA from calf thymus.

For the extraction tests (Section B), we prepared a $5 \mathrm{mM}$ Tris buffer ( $\mathrm{pH}$ 8.0) containing different concentrations of EDTA and/or sarcosine (N-lauroylsarcosine, sodium salt, L-9150, from Sigma). In the final procedure (Section $G$ ), when dealing with single organisms such as fish larvae, the extraction requires $1 \%$ STEB buffer (1\% sarcosine, $5 \mathrm{mM}$ Tris and $1 \mathrm{mM}$ EDTA, pH 8.0); in the case of samples collected on GF/F glass fibre filters, a 3.5\% STEB buffer $(3.5 \%$ sarcosine, $5 \mathrm{mM}$ Tris and $3.5 \mathrm{mM}$ EDTA, pH 8.0) is prepared.

The concentration of protein in microplankton samples (Section C) was detected with the NanoOrange fluorochrome (N-6666) following the procedure indicated by Molecular Probes, Inc. The assay was performed on $25 \mu \mathrm{l}$ of the nucleic acid extract. The adaptation of this method for microplankton samples will be found elsewhere (Roldán, in progress).

For the quantification of RNA and DNA with ethidium bromide $(\mathrm{EtBr})$ the reagents were prepared as indicated by Caldarone et al. (2001). The assay was run in Tris-EDTA (TE) buffer ( $5 \mathrm{mM}$ Tris, 0.5 mM EDTA, pH 7.5); $\mathrm{MgCl}_{2} \cdot 6 \mathrm{H}_{2} \mathrm{O}$ and $\mathrm{CaCl}_{2} \cdot 2 \mathrm{H}_{2} \mathrm{O}$ (both at $0.9 \mathrm{mM}$ final concentration) were added in the DNase digestion assay only. The EtBr (\#160539, Sigma) stock solution was made in distilled water $\left(1 \mathrm{mg} \mathrm{ml}^{-1}\right)$ and the working solution in Tris-EDTA buffer at $20 \mu \mathrm{g} \mathrm{ml}^{-1}$; a $1 \mu \mathrm{g} \mathrm{ml}^{-1}$ final concentration was used. 
Assay procedures

All RNA and DNA analyses were done with the SYBR Green II (SG-II) and nuclease assays described in the accompanying paper (Berdalet et al., 2005: Section K). When using EtBr we followed the protocol of Caldarone et al. (2001) adapted for 1 $\mathrm{ml}$ assays with minor modifications described in Section E.

\section{Fluorescence readings}

Fluorometric readings were performed according to Berdalet et al. (2005: Section B) using quartz cuvettes. Some data were obtained with a Shimadzu RF-570 spectrofluorometer and others with an Aminco-Bowman 2. Relative fluorescence is expressed as fluorescein equivalent units (FEU, in $\mathrm{nM}$ ).

\section{(B) Extraction and freezing tests}

\section{Interference of the extraction reagents}

Do sarcosine and EDTA interfere with the fluorescence response of the nucleic acids after binding to SG-II, and/or with the efficiency of the nucleases?

RNA (RNA-Y, rRNA-L) and DNA (DNA-T, uDNA-T) standard curves incubated with DNase or RNase respectively, and with different concentrations of sarcosine (from 0 to $0.0125 \%$ ) and/or EDTA (from 0 to $50 \mu \mathrm{M}$ ) were run. The standards were prepared as described in Berdalet et al. (2005: Section A and Table 2).

\section{Improvement of the detergent based extraction}

The detergent based extraction method (Canino and Caldarone, 1995) was compared to the extraction using Tris buffer alone in fish larvae (Extraction experiment A) and in monospecific phytoplankton cultures collected on GF/F glass fibre filters (Extraction experiment $\mathrm{B})$.

For Extraction experiment A, five Sardina pilchardus larvae (17.5-21 mm, total length) were deep-frozen in liquid nitrogen and subsequently maintained at $-80^{\circ} \mathrm{C}$ until analysis. After removing the head and gut contents, the individual larvae were homogenised in a Potter-Elvehem tissue grinder on ice in $250 \mu \mathrm{l}$ Tris buffer. Each homogenate was divided into 2 parts (120 $\mu \mathrm{l}$ each) which were dilut- ed 1:1 with either Tris buffer alone or 1\% STEB buffer; in this way the extraction with "Tris alone" was compared with that with " $0.5 \%$ sarcosine". After $60 \mathrm{~min}$ at RT, the homogenate was centrifuged, a part of the supernatant fluid was diluted 1:10 with $5 \mathrm{mM}$ Tris buffer, and $250 \mu \mathrm{l}$ of this mixture was used per $1 \mathrm{ml}$ assay. In this short experiment, the extraction and analysis were performed on the same day. The calculations were made using RNA-Y and DNA-T standards containing the final concentration in the assay of STEB used in every extraction treatment tested, specifically 0 or $0.0125 \%$ sarcosine, and 0 or $12.5 \mu \mathrm{M}$ EDTA.

For Extraction experiment B, nine samples of the dinoflagellate Alexandrium minutum were collected on $25 \mathrm{~mm} \mathrm{GF} / \mathrm{F}$ glass fibre filters and immediately frozen in liquid nitrogen. Each filter (80 ml culture containing 13300 cells ml-1) was ground using a Potter-Elvehem tissue grinder with $2 \mathrm{ml}$ of Tris buffer on ice. The homogenates were pooled together to obtain three $6 \mathrm{ml}$ extracts, which were subsequently split into three $1.5 \mathrm{ml}$ fractions. Each fraction was diluted 1:1 with Tris buffer alone, $1 \%$ STEB buffer or 2\% STEB buffer (2\% sarcosine, $5 \mathrm{mM}$ Tris, $1 \mathrm{mM}$ EDTA, $\mathrm{pH}$ 8.0); in this way three extraction treatments, "Tris alone", "0.5\% sarcosine" and " $1 \%$ sarcosine", were compared. The extraction was helped by continuous shaking for $60 \mathrm{~min}$ using a multihead vortex at RT. Each extract was divided into two fractions; one of them was reserved to continue with the preservation tests (Section B) and the other one (containing both filter and cell debris) was centrifuged and frozen $\left(-80^{\circ} \mathrm{C}\right)$. On the day of analysis, the extracts were thawed and centrifuged again, and the supernatant fluid was diluted 1:10 with Tris buffer. The $1 \mathrm{ml}$ assays contained $125 \mu \mathrm{l}$ of the diluted extracts. rRNA-L and uDNA-T were used as standards containing $0,0.00625$ or $0.0125 \%$ sarcosine, and 0 or $6.25 \mu \mathrm{M}$ EDTA, to match each extraction treatment.

\section{Preservation of extracts at $-80^{\circ} \mathrm{C}$ prior to analysis}

Performing the extractions and the assays on separate days can be convenient. However, does freezing the extract at $-80^{\circ} \mathrm{C}$ for several days prior to the analysis adequately preserve the nucleic acid samples? To answer this question, natural microplankton samples $(n=24)$ were collected by gentle filtration onto $\mathrm{GF} / \mathrm{F}$ glass fibre filters and manipulated according to the final procedure in order to obtain 
the " $0.5 \%$ homogenate" (Section G). Each sample was split into 3 aliquots to be analysed immediately or to be frozen at $-80^{\circ} \mathrm{C}$ and analysed in the subsequent 7 or 28 days.

We also tested whether freezing $\left(-80^{\circ} \mathrm{C}\right)$ a diluted (1:10) extract resulted in sample losses compared to the non-diluted one. This experiment was part of Extraction experiment B (Section B). One of the aliquots of each kind of extract (i.e. "Tris alone", "0.5\% sarcosine" or " $1 \%$ sarcosine") was diluted 1:10 in Tris buffer before freezing. On the day of analysis, after thawing, they were centrifuged and $125 \mu \mathrm{l}$ of the supernatant fluid was used per $1 \mathrm{ml}$ assay. The data were compared with the parallel aliquots frozen without previous dilution. In the two tests, rRNA-L and DNA-T were used as standards.

\section{(C) Linearity, sensitivity, precision and accuracy}

The following tests were based on either phytoplankton cultures or natural microplankton communities from NW Mediterranean coastal waters. All samples were collected on $25 \mathrm{~mm} \mathrm{GF/F}$ glass fibre filters and processed according to the final procedure (Section G). The " $0.5 \%$ homogenates" were aliquoted and frozen $\left(-80^{\circ} \mathrm{C}\right)$ until analysis. rRNA$\mathrm{L}$ and DNA-T were used as standards.

\section{Linearity and sensitivity}

We investigated whether increasing the amount of extract used in the three assays of the final procedure (i.e. DNase, RNase and Residual) resulted in a linear increase of the fluorescence response and consequently allowed the correct estimation of the RNA and DNA concentration per sample. The test was run on a natural microplankton sample. The three assays used either $50,100,150$ or $200 \mu l$ of the " $0.05 \%$ extract". STEB buffer was added in amounts to give $0.01 \%$ sarcosine per assay (final concentration). The level of protein biomass used per assay was quantified with NanoOrange on a 25 $\mu l$ aliquot of the " $0.5 \%$ homogenate".

\section{Precision}

To determine the precision of the final extraction plus assay procedure we evaluated the coefficient of variation, $\mathrm{CV}(\%)=($ standard deviation/average $) \mathrm{x}$ 100 , of the estimations of RNA and DNA concentrations and their resulting RNA/DNA ratios, at the following three levels of variability. "Within the assay", from the " $0.05 \%$ extract" of a natural microplankton community sample, 18 aliquots ( 250 $\mu 1$ each) were distributed to run 6 replicates of the DNase, RNase and Residual assays. "Within the extract", three different samples from natural microplankton communities were processed to obtain the " $0.5 \%$ homogenates" which were distributed in 5 aliquots $(350 \mu \mathrm{l})$ containing both filter and cell debris, and frozen at $-80^{\circ} \mathrm{C}$; all aliquots were analysed using $250 \mu \mathrm{l}$ of the " $0.05 \%$ extract" per 1 $\mathrm{ml}$ assay. "From day-to-day", this test was performed on samples from Rhodomonas sp. and a mixture of dinoflagellate cultures (Akashiwo sanguinea, Alexandrium minutum and Prorocentrum minimum). From each " $0.5 \%$ homogenate" (containing both filter and cell debris), several $750 \mu 1$ aliquots were distributed and frozen $\left(-80^{\circ} \mathrm{C}\right)$. Four aliquots were analysed on 4 consecutive days, using $50 \mu 1$ each " $0.05 \%$ extract" per $1 \mathrm{ml}$ assay.

\section{Accuracy}

The accuracy of the method was approached through an RNA and DNA recovery rates test using a natural microplankton sample. The " $0.05 \%$ extract" was distributed into several $250 \mu \mathrm{l}$ aliquots which were mixed with increasing concentrations of either RNA $\left(0,80,120\right.$ and $\left.160 \mathrm{ng} \mathrm{ml}^{-1}\right)$ or DNA $(0$, 20, 30 and $40 \mathrm{ng} \mathrm{ml}^{-1}$ ) standards and analysed with SG-II after DNase or RNase incubation respectively; the same RNA and DNA standard curves were also run without the natural extract. The results are expressed as the proportion (in \%) between the measured and expected RNA and DNA concentrations of the spiked standards.

\section{(D) RNA/DNA ratios from natural samples}

The final extraction and assay procedure (Section G) was used for the analysis of samples obtained during two laboratory experiments with fish larvae and with natural microbial communities.

\section{RNA/DNA experiment 1. Dicentrarchus labrax} larvae

This experiment was conducted within the framework of a project aimed at comparing different indicators of the nutritional and physiological status of fish larvae. Sea bass (Dicentrarchus labrax) larvae were hatched in the laboratory from a naturally 
spawned female. The larvae were reared in a closed recirculation system at $20^{\circ} \mathrm{C}$ and a 9:15 h light:dark photoperiod (Olivar et al., 2000). Four days after hatching the larvae were split into two groups. The first one received a daily food supply ("fed larvae") consisting of live prey (rotifers, Artemia nauplii and enriched Artemia metanauplii, depending on their age), according to Barnabé (1985). No food was given to the second group ("non-fed larvae"). Because D. labrax larvae retained maternal food reserves (yolk or oil globule) during the first 13 days of life, only the RNA/DNA ratios measured in larvae from day 14 to day 18 after hatching were compared in this study. Daily samples (3-8 larvae per treatment) were taken (before food addition in the case of the "fed larvae" group). Each larva (4.7-7.7 $\mathrm{mm}$ total length) was processed individually. RNA$\mathrm{Y}$ and DNA-T were used as standards.

\section{RNA/DNA experiment 2. Microplankton communi-} ties in microcosms

The experimental microcosm setup (Peters et al., 2002) consisted of 4 plexiglass cylinders filled with 151 of coastal water collected from Masnou (a locality $20 \mathrm{~km}$ north of Barcelona) and filtered through a $150 \mu \mathrm{m}$ nylon mesh. The microcosms were maintained in a constant temperature chamber at $19^{\circ} \mathrm{C}$,

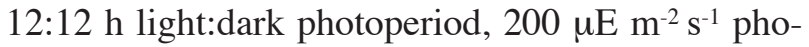
tosynthetically active irradiance (PAR) and constant turbulence $\left(0.05 \mathrm{~cm}^{2} \mathrm{~s}^{-3}\right)$. After enclosure each microcosm received a nutrient enrichment consisting of $0,4,8$ or $16 \mu \mathrm{M}$ nitrate, and phosphate at the corresponding Redfield ratio (i.e. $\mathrm{N}: \mathrm{P}=16$; Redfield et al., 1963). Accordingly, the treatments are referred to as N0, N4, N8 and N16. All treatments also received silicate at a concentration twice that of the added nitrate and a metal supplement in the nanomolar range, but in the same proportion of nitrate according to Guillard (1975). Daily samples were taken to estimate nutrient concentration, biomass of several planktonic groups and other biochemical indicators. Samples for nucleic acids were collected on precombusted $\left(450^{\circ} \mathrm{C}, 4 \mathrm{~h}\right) 25 \mathrm{~mm}$ $\mathrm{GF} / \mathrm{F}$ glass fibre filters. rRNA-L and uDNA-T were used as standards.

\section{(E) Comparison with ethidium bromide}

We compared the RNA and DNA concentrations quantified by SG-II and by EtBr in the same homogenate in which the three assays (namely,
DNase, RNase and Residual) were run. Five Engraulis encrasicolus larvae [0.094-0.778 mg dry weight (DW); 8-11.3 mm total length] were processed essentially with the final extraction plus assay procedure (Section $\mathrm{G}$ ), with some modifications to allow the use of the two fluorochromes in the same homogenate. Each individual " $0.5 \%$ homogenate" (150 $\mu 1)$ was split into two: $120 \mu 1$ were used for the quantification by $\mathrm{EtBr}$ and 15-20 $\mu 1$ for the SG-II method. The two homogenates were diluted 1:10 with $\mathrm{TE}$ (for $\mathrm{EtBr}$ analysis) or Tris buffer (for the SG-II one) to obtain the " $0.05 \%$ extracts". From them, three aliquots of $350 \mu \mathrm{l}$ or of $60 \mu \mathrm{l}$ were taken respectively, for quantification by EtBr or by SG-II, all in $1 \mathrm{ml}$ assays. Standard curves of rRNA-L and uDNA-T were run for each fluorochrome. The nucleic acid standards were made up in the corresponding buffer and incubated with the two nucleases (Berdalet et al., 2005: Section K) and with the final concentration of STEB buffer used in each set of samples, i.e. $0.003 \%$ sarcosine in the SG-II assays and $0.0175 \%$ in the $\mathrm{EtBr}$ ones. This last concentration of sarcosine resulted from the high biomass requirement in the $\mathrm{EtBr}$ assay and was slightly higher than the maximum indicated by Canino and Caldarone (1995). However, it did not significantly affect the RNA and DNA standard curves used for the calculations (not shown).

\section{RESULTS AND DISCUSSION}

\section{(F) Extraction and freezing tests}

\section{Interference of the extraction reagents}

The presence of sarcosine in the assay caused a marked increase in the y-intercepts and a significant $(p<0.05)$ decrease in the slopes of the RNA and DNA standard curves compared to the ones run without detergent (Fig. 1, Table 1), but had no effect on the residual fluorescence. At sarcosine concentrations $\geq 0.0125 \%$, the fluorescence values showed a certain oscillation (not shown). In consequence, the highest final concentration of sarcosine in the assay was set at $\leq 0.01 \%$.

None of the concentrations of EDTA tested (alone or in combination with sarcosine) caused a major effect on the fluorescent response of RNA and DNA standard curves or on the residual fluorescence (not shown). 

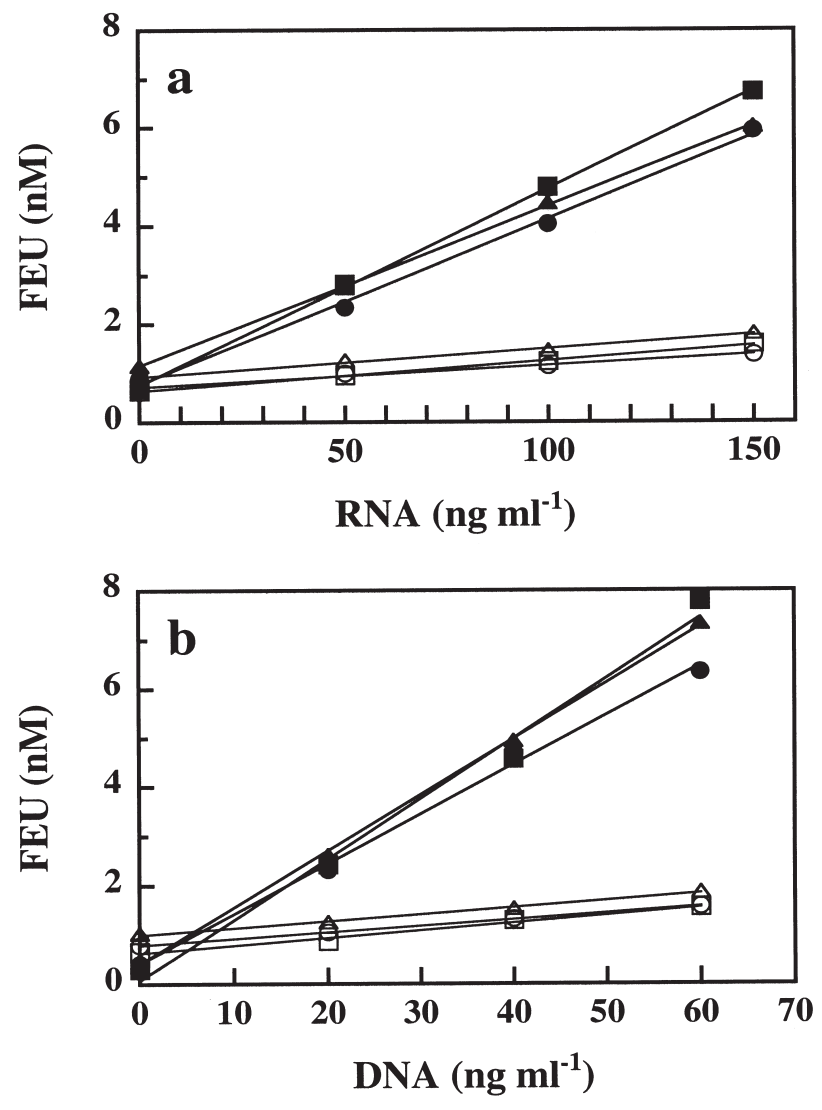

FIG. 1. - RNA (a) and DNA (b) standard curves run with Tris buffer alone (squares) or in Tris buffer with $0.5 \mathrm{mM}$ EDTA and with sarcosine at $0.00625 \%$ (circles) or $0.0125 \%$ (triangles) final concentration in the assay. Closed symbols: RNA standards incubated with DNase (in a) or DNA standards incubated with RNase (in b). Open symbols: RNA or DNA standards incubated in the presence of their corresponding degrading nuclease (base lines). Details in sections B and F. FEU: Fluorescein Equivalent Units (nM). The regression lines and statistics are given in Table 1.

\section{Improvement of the detergent based extraction}

In the two Extraction experiments $\mathrm{A}$ and $\mathrm{B}$, the RNA and DNA concentrations measured in "Tris alone" were significantly lower than using any detergent based extraction $(\mathrm{p}<0.05$ in all KruskalWallis one way non-parametric analyses of variance tests run). In Extraction experiment A, the RNA and the DNA extracted using "Tris alone" were $49.7 \% \pm$ 6.4 and $43.4 \% \pm 2.0$ (mean $\pm \mathrm{SEM}, \mathrm{n}=5$ ) respectively of the values obtained using the " $0.5 \%$ sarcosine" treatment (not shown).

In Extraction experiment B the RNA and DNA concentrations measured in "Tris alone" were $59.1 \%$ \pm 2.6 and $52.4 \% \pm 1.1$ (mean $\pm \mathrm{SEM}, \mathrm{n}=3$ ) respectively of the values obtained with the extraction on " $0.5 \%$ sarcosine". Compared to the extraction with "1\% sarcosine" (Fig. 2), the RNA and DNA extracted with "Tris alone" accounted for $49.4 \% \pm 1.9$ and $56.2 \% \pm 1.3$ (mean \pm SEM, $\mathrm{n}=3$ ) respectively.

Overall, the concentration from extraction with " $0.5 \%$ sarcosine" doubled that of "Tris alone". However, there was no clear improvement extracting with " $1 \%$ sarcosine": while the RNA extraction increased significantly $(\mathrm{p}<0.016)$, that of DNA decreased $(p<0.01)$. Further, extraction with " $1 \%$ sarcosine" requires an additional 1:2 sample dilution to decrease the final concentration of the detergent in the assay down to at least $0.01 \%$. In the end, we decided to conduct extractions with $0.5 \%$ sarcosine.

TABLE 1. - Regression lines corresponding to the RNA and DNA standards run with Tris alone, 0.00625 or $0.0125 \%$ sarcosine illustrated in Fig. 1 and described in sections B and F. For each type of standard, the extraction on Tris alone was compared with the detergent treatment by performing heterogeneity of slopes tests using SYSTAT 5.2.1; "p" indicates the degree of significant differences found. " $\%$ residual" refers to the proportion between the slope of the RNA+RNase (or of the DNA+DNase) standard curve and that of the RNA+DNase one (or of the DNA+RNase) for each given amount of sarcosine.

\begin{tabular}{|c|c|c|c|c|c|}
\hline Treatment & $y$-intercept & slope & $\mathrm{r}$ & $\mathrm{p}$ & \%residual \\
\hline \multicolumn{6}{|l|}{ RNA + DNase } \\
\hline Tris alone & 0.756 & 0.04012 & 0.99982 & & \\
\hline $0.00625 \%$ sarcosine & 0.785 & 0.03370 & 0.99822 & 0.002 & \\
\hline $0.0125 \%$ sarcosine & 1.153 & 0.03266 & 0.99983 & 0.001 & \\
\hline \multicolumn{6}{|l|}{ RNA + RNase } \\
\hline Tris alone & 0.645 & 0.00620 & 0.99906 & & 15.5 \\
\hline $0.00625 \%$ sarcosine & 0.722 & 0.00444 & 0.99103 & 0.010 & 13.2 \\
\hline $0.0125 \%$ sarcosine & 0.933 & 0.00576 & 0.99595 & 0.050 & 17.6 \\
\hline \multicolumn{6}{|l|}{ DNA + RNase } \\
\hline Tris alone & 0.081 & 0.12305 & 0.99420 & & \\
\hline $0.00625 \%$ sarcosine & 0.430 & 0.10100 & 0.99752 & 0.032 & \\
\hline $0.0125 \%$ sarcosine & 0.432 & 0.11410 & 0.99960 & 0.282 & \\
\hline \multicolumn{6}{|l|}{ DNA + DNase } \\
\hline Tris alone & 0.649 & 0.01545 & 0.99227 & & 12.6 \\
\hline $0.00625 \%$ sarcosine & 0.804 & 0.01320 & 0.99984 & 0.020 & 13.1 \\
\hline $0.0125 \%$ sarcosine & 1.102 & 0.01400 & 0.99683 & 0.047 & 12.3 \\
\hline
\end{tabular}



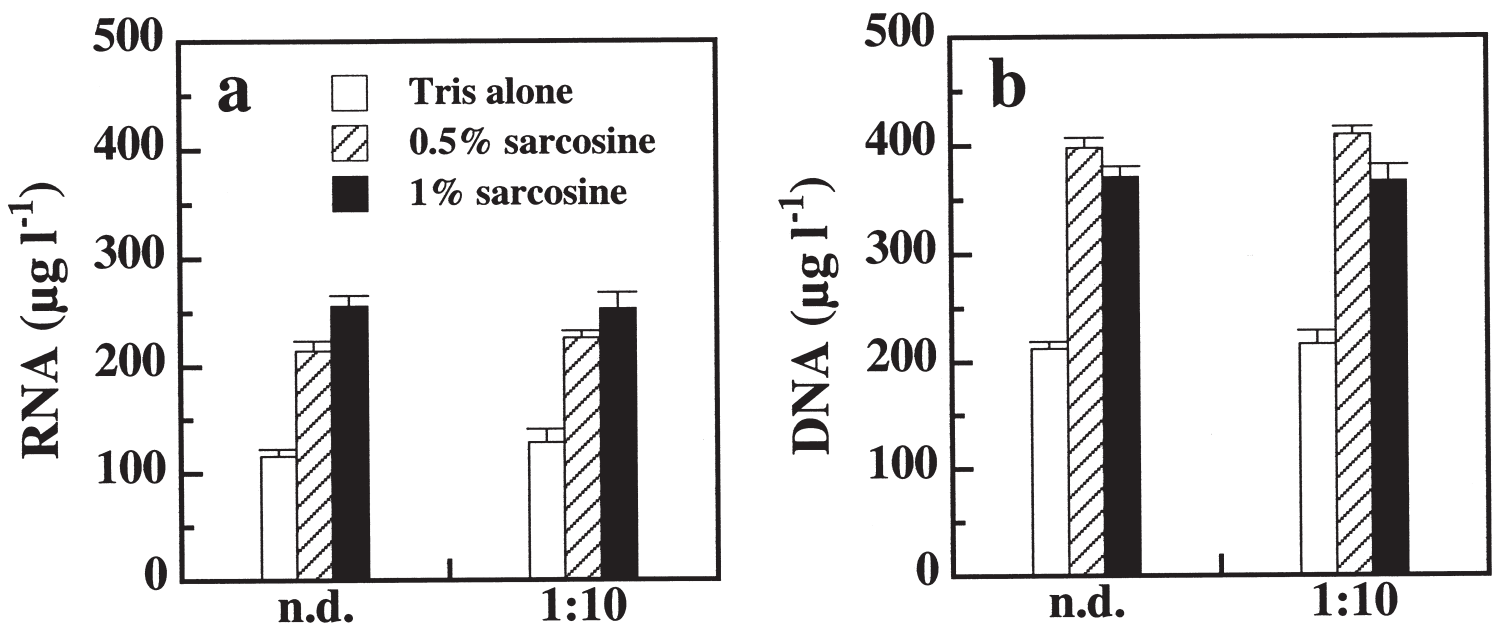

FIG. 2. - RNA (a) and DNA (b) concentrations ( $\mu \mathrm{g}$ per liter of culture) estimated in the Extraction experiment B on Alexandrium minutum samples extracted with Tris buffer alone, $0.5 \%$ or $1 \%$ sarcosine. After 1 hour extraction in the selected buffer, part of the homogenate was immediately frozen without previous dilutions (n.d.); the other part was diluted in Tris buffer and then frozen (1:10). Details in sections B and F. The legend for Fig. $2 \mathrm{~b}$ is inside Fig. $2 \mathrm{a}$.

In the two extraction experiments described above, the samples had been first mechanically ground with a tissue grinder in the presence of Tris buffer, and subsequently extracted chemically with sarcosine and EDTA. Canino and Caldarone (1995) used a similar procedure with fish larvae. Recently, in several studies the samples were extracted in $1 \%$ STEB by continuously shaking for $1 \mathrm{~h}$ using a multivortex without any previous homogenisation with a tissue grinder. Wagner et al. (1998) applied this approach to copepods, Caldarone et al. (2001) to fish larvae and juveniles and, Gorokhova and Kyle (2002) to Daphnia. However, we observed that this method did not yield good homogenates when dealing with either GF/F glass fibre filter collected samples or freeze-dried larvae. Thus, samples are homogenised using teflon-glass tissue grinders with Tris buffer followed by chemical extraction in $0.5 \%$ STEB buffer at RT for $1 \mathrm{~h}$. Note that the final concentration of sarcosine for the extraction, namely $0.5 \%$, can be reached by combining different proportions of the Tris buffer (in which the mechanical grinding is performed) and a concentrated STEB buffer (e.g. Section G). Care must be taken because sarcosine easily precipitates at concentrations above $3.5 \%$.

\section{Preservation of extracts at $-80^{\circ} \mathrm{C}$ prior to analysis}

There were no significant differences between the RNA and DNA concentrations estimated immediately following sample extraction in $0.5 \%$ STEB buffer and the values measured in the aliquots of the extracts maintained at $-80^{\circ} \mathrm{C}$ for either 7 or 28 days (not shown). Specifically, the statistics (at $n=24$ ) obtained in the comparison between freshly analysed extracts and the 7 day-frozen ones were: $U=160.0, p=0.377$ for the RNA concentration, and $U=159.0, p=0.475$ for the DNA concentration (Mann-Whitney U test, non-parametric Kruskall-Wallis one-way analysis of variance). In the comparison between fresh and 28 day-frozen extracts the statistics were $\mathrm{U}=241.5, \mathrm{p}=0.338$ for the RNA concentration and $\mathrm{U}=338.0, \mathrm{p}=0.187$ for the DNA concentration. The extracted homogenate can be diluted $1: 10$ before freezing at $-80^{\circ} \mathrm{C}$ without significant variation compared to freezing it without dilution (Fig. 2), independently of the concentration of detergent used in the extraction. In the final procedure, once extracted in $0.5 \%$ STEB, the homogenates (hereafter called " $0.5 \%$ homogenates") are frozen at $-80^{\circ} \mathrm{C}$ and the analysis is conducted on subsequent days. From these results, we established the extraction and freezing procedure that was compatible with the fluorometrical assay as described in Section G.

\section{(G) Final procedure}

The final procedure adapted to a fish larva (Fig. 3a) and a GF/F glass fibre filter collected sample (Fig. 3b) follows the next steps:

Step 1) Preservation: Freeze samples in liquid nitrogen immediately after collection; maintain either at $-196{ }^{\circ} \mathrm{C}$ (liquid nitrogen) or at $-80^{\circ} \mathrm{C}$ until analysis.

Step 2) Mechanical extraction:

2.1) Thaw sample slightly; in the case of fish larvae, remove head and gut content (Fig. 3a). 


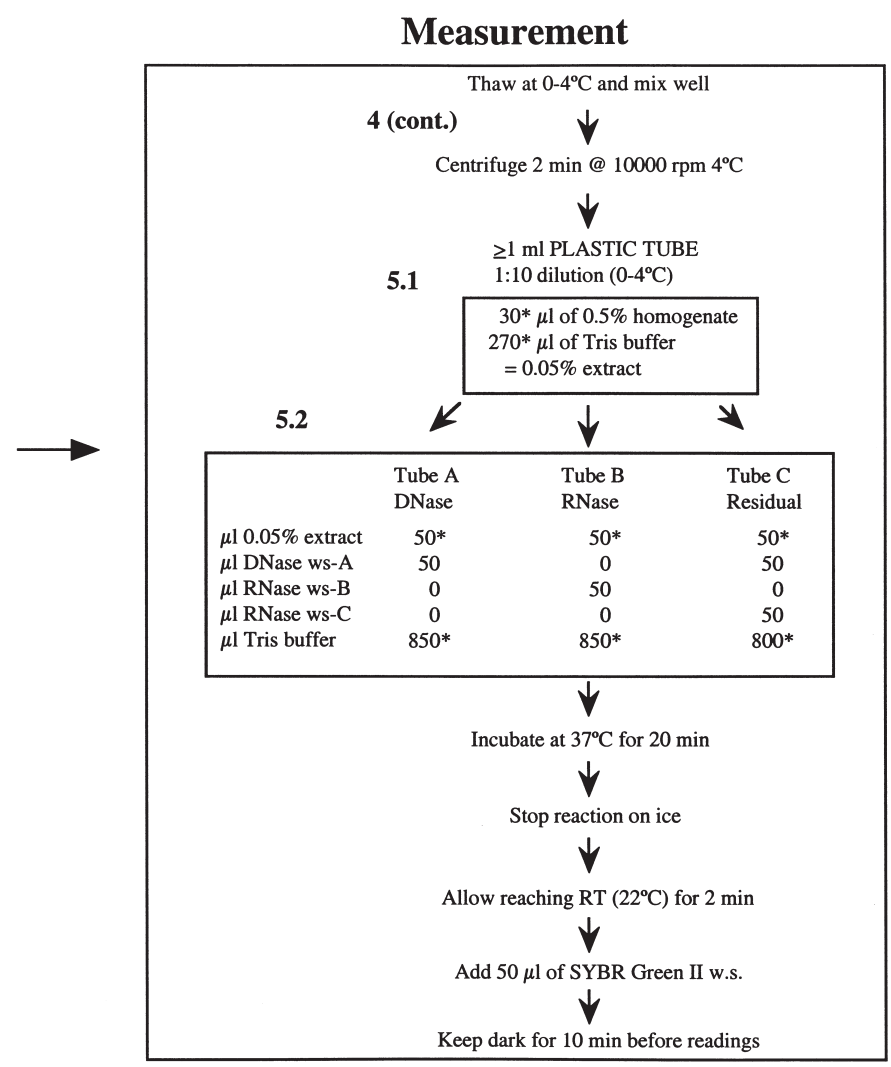

b

\section{Extraction}
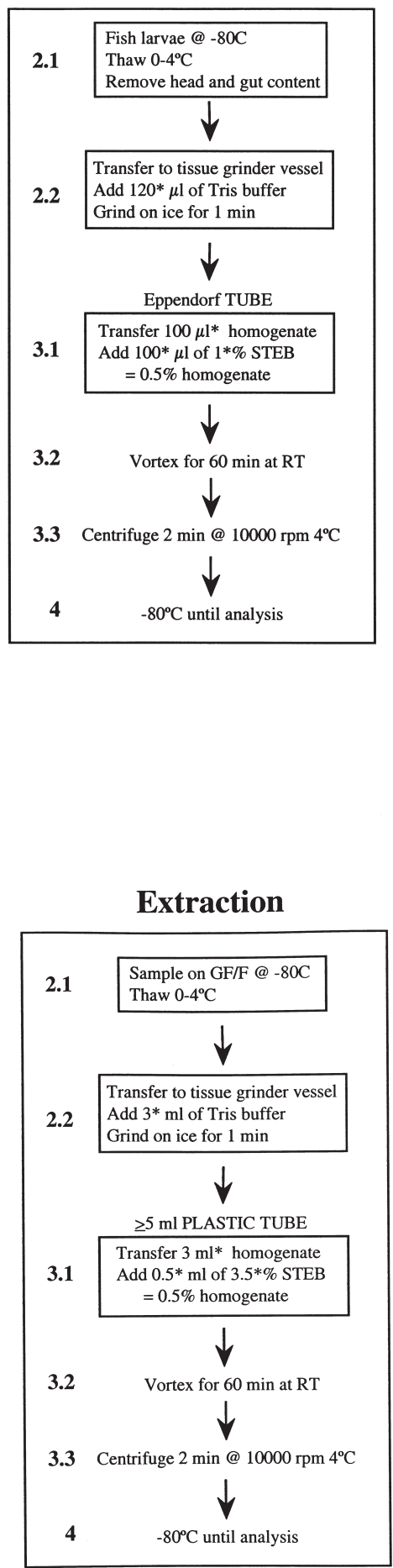

\section{Measurement}

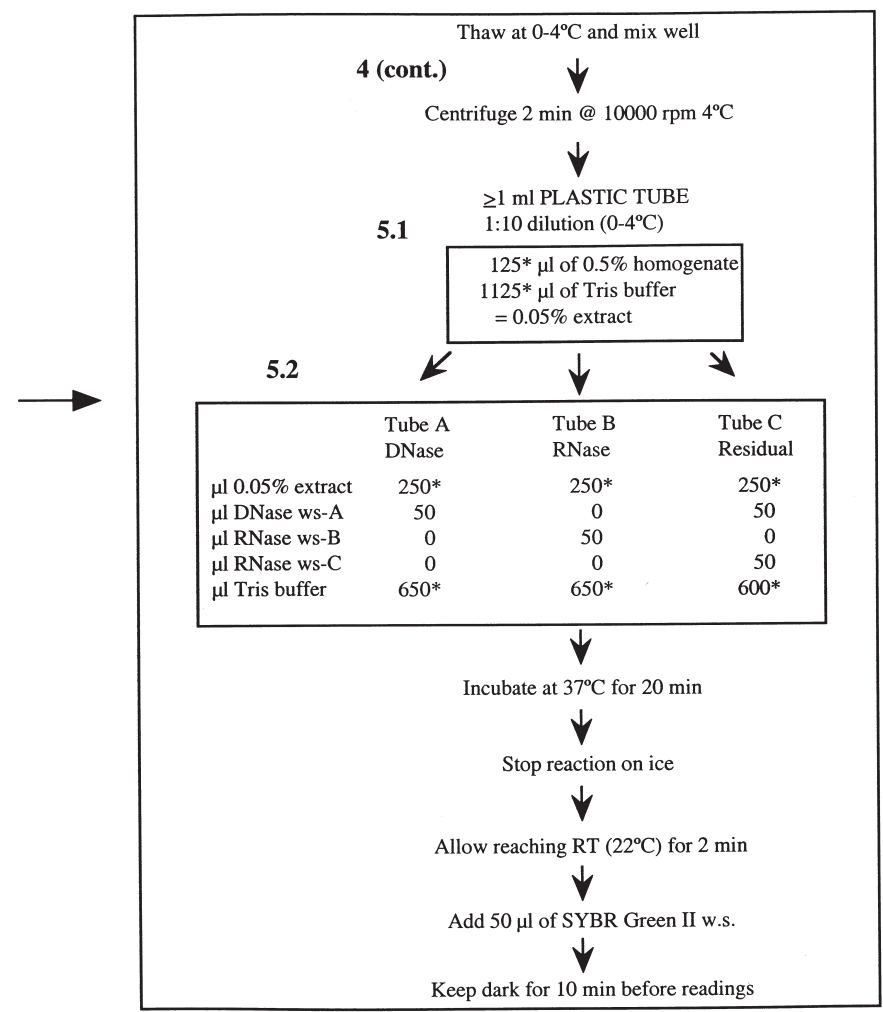

FIG. 3. - Final protocol adapted to different samples: a fish larvae (a) and a microplankton sample collected in a GF/F glass fibre filter (b). The asterisks $(*)$ indicate the values that can be changed depending on the biomass of the sample (section G). Left numbers correspond to the steps outlined in section $\mathrm{G}$. 
2.2) Grind sample on ice for 1 min with a teflon-glass tissue grinder. Use the smallest reliable volume of Tris buffer. For instance, a fish larvae up to $12 \mathrm{~mm}$ can be ground in $120 \mu \mathrm{l}$ (Fig. 3a) using a $2 \mathrm{ml}$ tissue grinder. A $25 \mathrm{~mm} \mathrm{GF} / \mathrm{F}$ glass fibre filter can be ground with $3 \mathrm{ml}$ of buffer in a $5 \mathrm{ml}$ tissue grinder (Fig. 3b).

Step 3) Chemical extraction:

3.1) Transfer the homogenate to a plastic tube. Note the volume effectively transferred (e.g. $100 \mu$ l, Fig. 3a). Add the STEB buffer at the adequate concentration and proportion such that the homogenate is extracted on $0.5 \%$ sarcosine. For instance, in Figure $3 \mathrm{a}$, the fish larvae homogenate is mixed 1:1 with $1 \%$ STEB buffer. In Fig. 3b, $0.5 \mathrm{ml}$ of $3.5 \%$ STEB buffer are added to the $3 \mathrm{ml}$ filter homogenate. The mixture is now referred to as " $0.5 \%$ homogenate" because it contains $0.5 \%$ sarcosine.

3.2) Whenever possible, the " $0.5 \%$ homogenate" is continuously shaken in a multihead vortex at the highest reasonable speed at RT for 60 min. Otherwise, the sample is well mixed every 15 min during the same 60 min period.

3.3) Centrifuge (e.g. $10000 \mathrm{rpm}, 2 \mathrm{~min}, 4^{\circ} \mathrm{C}$ ) to pellet cell and filter debris. If the assay is not conducted immediately, go to Step 4). Otherwise, continue to Step 5).

Step 4) The "0.5\% homogenates" (divided into aliquots as necessary) can be stored frozen (at $-80^{\circ} \mathrm{C}$ ). On the day of analysis, they are thawed, mixed well and centrifuged (e.g. $10000 \mathrm{rpm}, 2 \mathrm{~min}$, $\left.4^{\circ} \mathrm{C}\right)$.

\section{Step 5) Analysis:}

5.1) Make a 1:10 dilution of the homogenate (supernatant fluid) in Tris buffer, to obtain a " $0.05 \%$ extract" that contains $0.05 \%$ sarcosine. Alternately, this dilution can be performed according to Step 3.2.

5.2) From the " $0.05 \%$ extract", the three aliquots (e.g. $50 \mu \mathrm{l}$ in Fig. 3a; $250 \mu \mathrm{l}$ in Fig. 3b) are taken to run the DNase (Tube A), the RNase (Tube B) and the Residual (Tube C) assays as described in Berdalet et al. (2005: Section K). Run the standard curves containing exactly the same final concentration of STEB buffer as the samples.

The volume of certain reagents can be adapted to the sample biomass and/or the presence of the GF/F glass fibre filter. The modifications (indicated with asteriscs in Fig. 3) include: 1) the volume of Tris buffer; 2) the proportion between the homogenate and the STEB to make a " $0.5 \%$ homogenate"; 3 ) the concentration of sarcosine in the STEB buffer; 4) the volume of the " $0.5 \%$ homogenate" used to be diluted 1:10 to make the " $0.05 \%$ extract"; and 5) the volume of " $0.05 \%$ extract" used per $1 \mathrm{ml}$ assay.

\section{Remarks}

- Optimal preservation of the nucleic acids is accomplished by freezing and keeping samples in liquid nitrogen. Long term maintenance at $-80^{\circ} \mathrm{C}$ until analysis is commonly used in many Molecular Biology procedures (Muyzer et al., 1996).

- Fish larvae can be freeze-dried (in order to measure DW) and maintained at $-80^{\circ} \mathrm{C}$ until analysis (e.g. Suthers, 1996, Caldarone et al., 2001; RossiWongtschowski et al., 2003).

- Choose the volume of extraction buffer that optimises effective grinding and high sensitivity, depending on the biomass of the sample.

- A priori, the " $0.5 \%$ homogenate" can be used directly (after thawing and centrifuging) to run the 1 $\mathrm{ml}$ assay provided that the final concentration of sarcosine was $\leq 0.01 \%$. However, a 1:10 dilution of the " $0.5 \%$ homogenate" is performed to avoid the variability associated with pipetting small volumes $(<5$ $\mu \mathrm{l})$. Use Tris $5 \mathrm{mM}(\mathrm{pH} 8.0)$ without $\mathrm{Ca}^{2+}$ and $\mathrm{Mg}^{2+}$ salts, to avoid precipitate formation in the extract.

- For accurate calculations, the standard curves must be run following, as far as possible, the overall manipulation of the samples. Thus, in the case of the samples collected on GF/F glass fibre filters, calculations are performed using standard curves with all components exposed to filters. Specifically, blank filters (precombusted $\mathrm{GF} / \mathrm{F}$ glass filters $-450^{\circ} \mathrm{C}, 4 \mathrm{~h}$ ) rinsed with $0.2 \mu \mathrm{m}$ filtered seawater and frozen in liquid nitrogen are ground with Tris buffer containing a known amount of RNA or DNA (in duplicate) standard and processed as outlined in Figure 3b. The slopes and residual fluorescences of the "ground" RNA or DNA standards are used for the calculations. In general, the slopes of those standards are lower than the daily standards not exposed to the filters. Apparently, the positive charge of the glass fibres may retain a fraction of the nucleic acids extracted. Running standard curves with filters is considerably time-consuming; they are therefore run only once during a series of analyses.

\section{(H) Linearity, sensitivity, precision and accuracy}

\section{Linearity and sensitivity}

SG-II exhibited a linear fluorometric response to increasing amounts of extract used in the three $1 \mathrm{ml}$ 

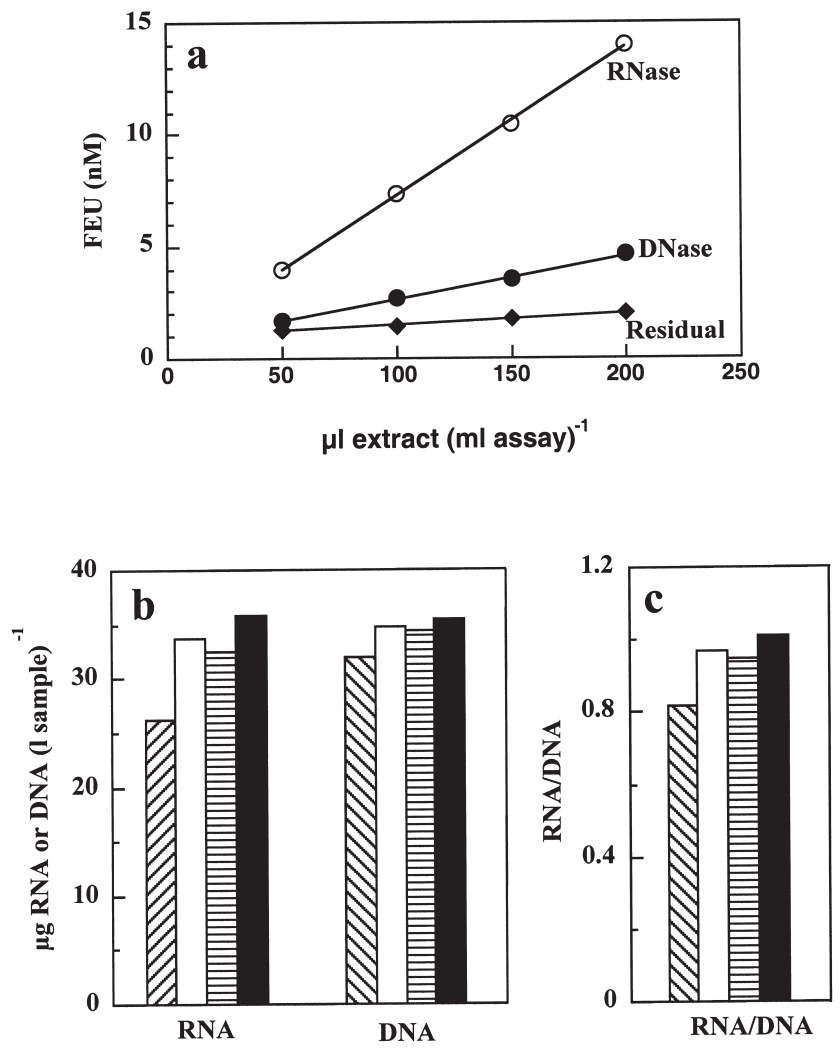

FIG. 4. - (a) Linear fluorescence response [expressed as Fluorescein Equivalent Units, FEU (nM)] of SG-II with increasing amounts of extract in the three $1 \mathrm{ml}$ assays of the final procedure (i.e. RNase, DNase and Residual). (b) Concentrations of RNA and DNA in the sample estimated using the different amounts of the extract illustrated in (a). (c) The corresponding RNA/DNA ratios. In b) and c) the white bar corresponds to $50 \mu 1$ extract; the hatched bar to 100 $\mu 1$; the grey bar to $150 \mu \mathrm{l}$ and the black bar to $200 \mu \mathrm{l}$. The assay conducted on $100 \mu \mathrm{l}$ of extract had a protein concentration of ca. $400 \mathrm{ng} \mathrm{ml}^{-1}$. Details in sections $\mathrm{C}$ and $\mathrm{H}$.

assays (Fig. 4a). However, coherent estimations of RNA and DNA concentrations and of RNA/DNA ratios per sample were mainly obtained above 100 $\mu l$ extract per assay (Figs. $4 \mathrm{~b}$ and $4 \mathrm{c}$ ), corresponding to $c a .400 \mathrm{ng}$ protein ( $\mathrm{ml}$ assay) ${ }^{-1}$. This level of sensitivity is $c a$. 20 times higher than our previous method, based on thiazole orange (Fara et al., 1996), which we used for microplankton samples. For larvae, we fixed a minimum biomass requirement at 3 $\mu \mathrm{g} \mathrm{DW}(\mathrm{ml} \text { assay) })^{-1}$ (ca. $5 \mathrm{~mm}$ individuals) based on our experimental data (some of them shown in the Section I). In terms of RNA and DNA, the level of sensitivity of this method was set at $c a .40$ ng RNA or 10 ng DNA (ml assay) $)^{-1}$.

This experimentally determined level of sensitivity is the result of the combination of: 1) the sensitivity of the fluorochrome itself; 2) the extraction with sarcosine which requires the dilution of the sample (Section F); and 3) the nuclease digestions (with the non-negligible residual fluorescence,
Berdalet et al., 2005) necessary to estimate RNA and DNA in crude extracts.

The level of sensitivity of the SG-II and nuclease procedure was that expected according to Molecular Probes. Higher sensitivity can be achieved by diluting the SG-II down to $2 \times 10^{-5}$ in the assay, $c a .17 .5$ times lower than the concentration fixed in our procedure (Schmidt and Ernst, 1995). However, under those conditions the fluorescence yield was highly sensitive to the nuclease incubations necessary for the nucleic acid quantification in crude extracts. Specifically, the slope of the DNA standard curve incubated with RNase was half that of the DNA alone (not shown) and a similar reduction occurred when RNA was incubated with DNase compared to the RNA alone. The diluted dye concentration indicated by Schmidt and Ernst (1995) applied on purified DNA extracts aimed at DGGE analysis without any nuclease incubations allowed the estimation of $1 \mathrm{ng}$ DNA $\mathrm{ml}^{-1}$ using $1 \mu \mathrm{l}$ of extract per $1 \mathrm{ml}$ assay in Tris buffer only (not shown).

Compared to EtBr, SG-II is nearly two orders of magnitude more sensitive according to Molecular Probes and to Schmidt and Ernst (1995). When EtBr was used in combination with sarcosine extraction and nucleases (Sections E and J), its detection limit was determined to be $c a .100 \mathrm{ng} \mathrm{ml}^{-1}$ DNA and 1000 ng ml-1 RNA, confirming that for both RNA and DNA SG-II is at least an order of magnitude more sensitive than EtBr.

\section{Precision}

The upper part of Table 2 shows the precision of the method depending on three different levels of variability. Within the assay, the coefficient of variation $(\mathrm{CV}, \%)$ of the estimations of the RNA and DNA concentrations and their resulting RNA/DNA ratios were low, i.e. 5.9, 1.6 and $6.9 \%$ respectively. At the level of the extract (whose variability includes the one of the assay), the CVs obtained in each sample tested did not exceed 9\%. Finally, at the highest level of variability, the one exhibited from day-to-day, the $\mathrm{CV}$ was $\leq 10 \%$ in the two different samples. The day-today variability includes the ones from the assay, the extract, the spectrofluorometer, the standard curves and the preservation over time procedures.

\section{Accuracy}

The three concentrations of RNA and of DNA added to the sample (Section C) were fully recov- 
TABLE 2. - Upper part: Precision of the final procedure evaluated at different levels of variability and expressed as the coefficient of variation, $\mathrm{CV}(\%)=($ standard deviation/average $) \times 100$, of the estimations of RNA and DNA concentrations and their resulting RNA/DNA ratios. Lower part: Accuracy of the method approached through the recovery rates test, expressed as the proportion (in \%) between the measured and expected RNA and DNA concentrations of the spiked standards.

\begin{tabular}{lcccc}
\hline Level of variability & RNA & DNA & RNA/DNA & $\mathrm{n}$ \\
\hline $\begin{array}{l}\text { Within the assay } \\
\text { Within the extract }\end{array}$ & 5.9 & 1.6 & 6.9 & 6 \\
sample 1 & 8.4 & 5.7 & 7.5 & 5 \\
sample 2 & 8.6 & 5.2 & 7.6 & 5 \\
sample 3 & 4.1 & 4.7 & 5.9 & 5 \\
$\begin{array}{l}\text { From day-to-day } \\
\text { Dinoflagellates }\end{array}$ & 4.13 & 6.46 & 9.35 & 4 \\
Rhodomonas sp. & 9.21 & 5.51 & 9.25 & 4 \\
Recovery rates test & $\%$ RNA & $\%$ DNA & & \\
average & 99.20 & 98.54 & & 3 \\
std & 2.16 & 1.86 & & \\
\hline
\end{tabular}

ered (Table 2, lower part; $99.20 \pm 2.16 \%$ and 98.54 $\pm 1.86 \%$ respectively; average \pm standard deviation, $\mathrm{n}=3$ ), indicating the accuracy of the procedure.

Overall, this part of the study showed the good linearity, sensitivity (10 ng DNA $\mathrm{ml}^{-1}$ and $40 \mathrm{ng}$ RNA $\left.\mathrm{ml}^{-1}\right)$, precision $(\mathrm{CV} \leq 10 \%)$ and accuracy of the procedure to quantify RNA and DNA in crude extracts of natural plankton samples characterised by low biomass.

\section{(I) RNA/DNA ratios from natural samples. Physiological information}

In the two experiments the RNA/DNA ratios measured were related to the different nutrient availability. In RNA/DNA experiment 1 with Dicentrarchus labrax larvae (Fig. 5), from day 14 the non-fed individuals showed significantly lower RNA/DNA ratios than the fed ones (Mann-Whitney test, $U=13$, $\mathrm{p}=0.000$; non-parametric Kruskall-Wallis one-way analysis of variance). The RNA/DNA values measured before day 14 showed a less consistent trend, probably due to the presence of oil globule reserves and the small biomass of the larvae (which was close to the detection limit of the method). In the RNA/DNA experiment 2 with microplankton communities, the values and the temporal variability of the RNA/DNA ratio (Fig. 6a) appeared to be linked to the nitrate concentration in the medium (Fig. 6b). After the enclosure of the microcosms, the development of the microplankton community is mainly supported by autotrophic organisms taking up nitrate. This nitrogen source is used to build up pro-

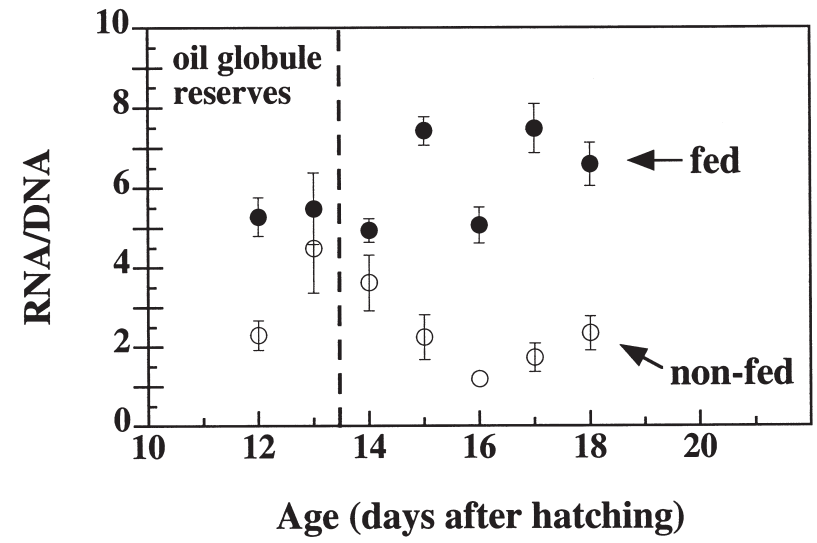

FIG. 5. - RNA/DNA ratios estimated in the feeding experiment conducted on Dicentrarchus labrax larvae. Vertical bars indicate the standard error of the mean. The shadow area corresponds to the days on which the oil globule was still present. Details in sections D and I.
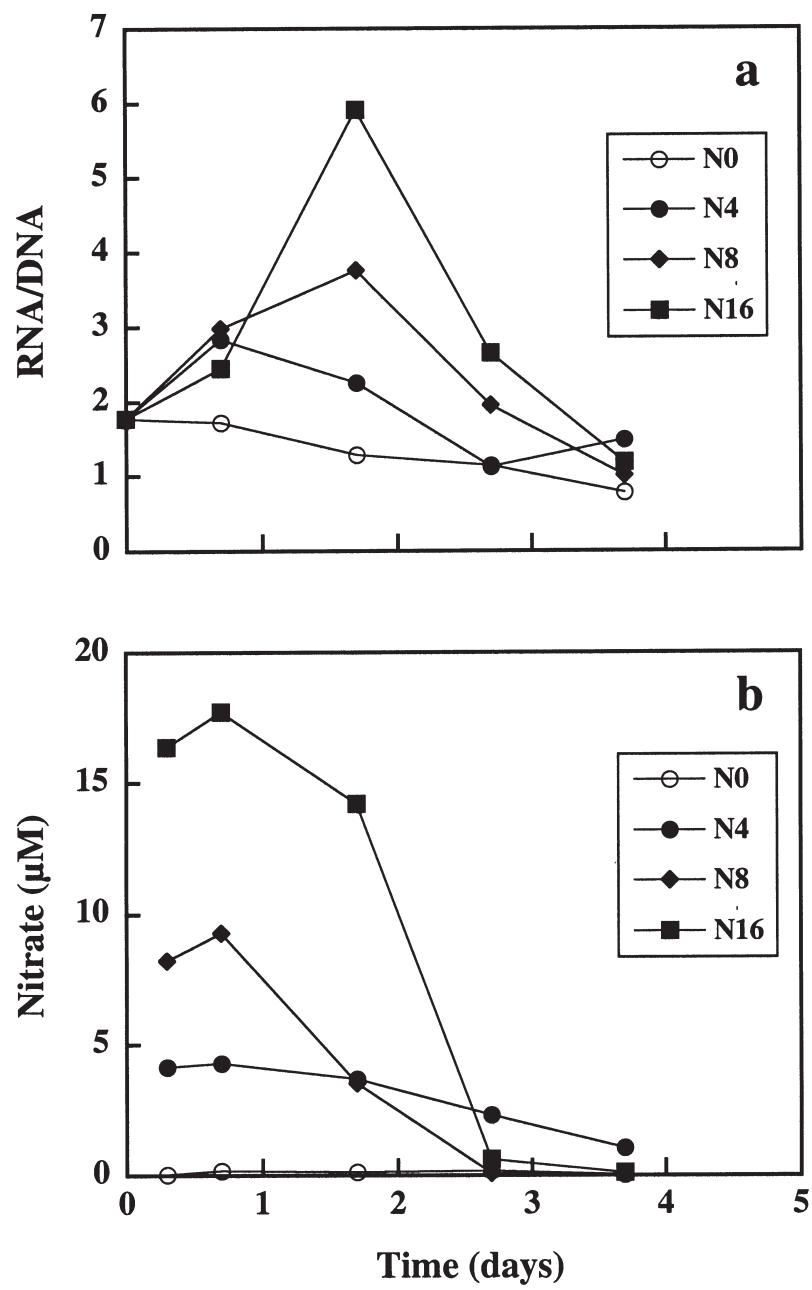

FIG. 6. - (a) Temporal variation of the RNA/DNA ratios estimated in natural microplanktonic communities enclosed in microcosms and exposed to different nutrient levels. (b) Temporal variation of the nitrate concentrations in the different treatments. N0, N4, N8 and N16 refer respectively, to the $0,4 \mu \mathrm{M}, 8 \mu \mathrm{M}$ and $16 \mu \mathrm{M}$ nitrate enrichments. Details in sections D and I. 
tein with a previous increase in the RNA synthesis per unit DNA in the cells. The highest RNA/DNA ratios were measured in the communities with a higher nitrate supply. Each microplankton community suffered a decline in its biosynthetic activity, when nitrate was exhausted in the medium.

In total, our developed procedure was able to provide RNA/DNA ratios with a meaningful ecophysiological interpretation, under controlled experimental conditions.

\section{(J) Comparison of SYBR Green II and ethidium bromide based data}

Can the RNA/DNA ratios measured in different organisms and/or experiments be compared? Given that the RNA/DNA ratio variability is species-specific (e.g. Berdalet et al., 1992), direct comparison of data obtained from different sort of organisms is not expected a priori. However, the absolute RNA/DNA value measured in any sample using a particular procedure also depends on the standards used for the calculations (Berdalet et al., 2005). On one side, the slope and the residual fluorescence of the selected standards determine the concentration of RNA and DNA estimated in the samples; on the other, the resulting RNA/DNA ratio depends on the ratio of the slope of the RNA to that of the DNA standard $\left(\mathrm{m}_{\mathrm{RNA}} / \mathrm{m}_{\mathrm{DNA}}\right)$ used. This information allows the comparison, for instance, of the two series of data from natural samples (Section I). In the experiment with fish larvae (Fig. 5), the calculations were based on RNA-Y and DNA-T standards (R-7125 and D-3664 from Sigma respectively) with an average $\mathrm{m}_{\mathrm{RNA}} / \mathrm{m}_{\mathrm{DNA}}$ ratio of $0.436 \pm 0.011$ (mean $\pm \mathrm{SEM}$, $\mathrm{n}=16$ ) using the Shimadzu RF-570 spectrofluorometer. In the experiment with microbial communities (Fig. 6), the $\mathrm{m}_{\mathrm{RNA}} / \mathrm{m}_{\mathrm{DNA}}$ ratio of the rRNA - L and uDNA - T standards (R-0889 and D-4764 from Sigma respectively) read on the Aminco-Bowman 2 spectrofluorometer, averaged $0.370 \pm 0.033($ mean \pm $\mathrm{SEM}, \mathrm{n}=2$ ). If this last ratio is taken as reference, the RNA/DNA ratios estimated in the fish larvae experiment can be normalised accordingly using the conversion factor that relates the two groups of standards, i.e. $0.370 / 0.436=0.849$.

This approach can also allow the comparison of the data obtained using the SG-II and nuclease procedure with other measures based on EtBr. The RNA and DNA estimations by the two fluorochromes were compared on the same homogenate, conducting the 3 fluorescence assays (RNase,
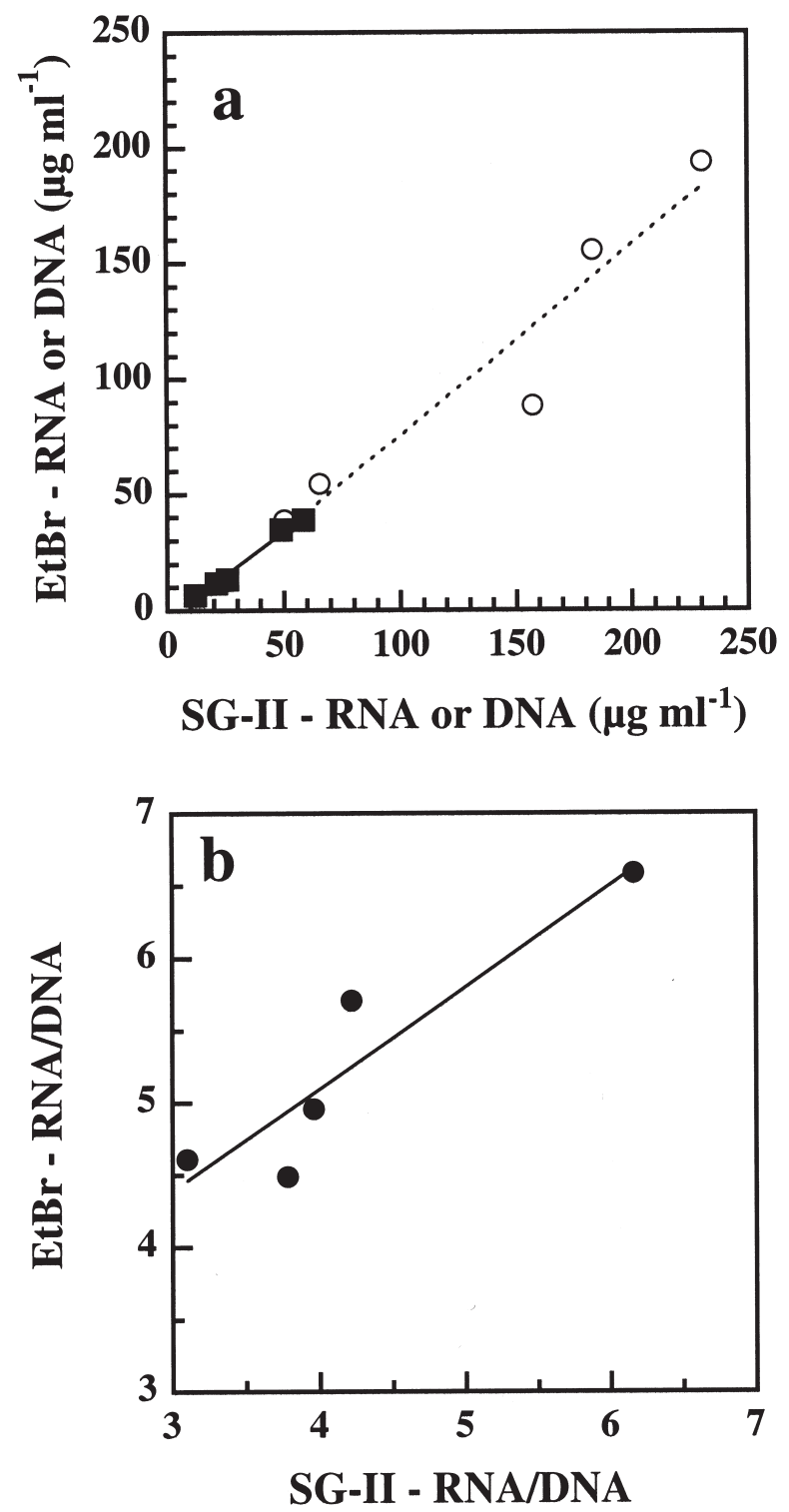

FIG. 7. - Comparison of the RNA and DNA measurements made with $\mathrm{EtBr}$ (y-axis) and SG-II (x-axis) in 5 individual larvae of Engraulis encrasicolus. Details in sections E and J. (a) RNA (open circles, dotted line) and DNA (filled squares, continuous line) concentrations ( $\mu \mathrm{g}$ per $\mathrm{ml}$ of extract); (b) the corresponding RNA/DNA (unitless) ratios. Details in sections E and J. For the RNA concentrations the regression line is: $\mathrm{y}=-5.9861+0.81862 \mathrm{x}, \mathrm{r}=0.95747$, $\mathrm{p}<0.01$; for the DNA concentration it is: $y=-3.3693+0.74353 x, r$ $=0.99332, \mathrm{p}<0.01 ;$ and for the RNA/DNA ratios it is: $\mathrm{y}=2.277+0.70571 \mathrm{x}, \mathrm{r}=0.92426, \mathrm{p}<0.01$.

DNase and Residual), and using the same standards (Section E). The RNA and DNA concentrations estimated with $\mathrm{EtBr}$ were lower, but within the same order of magnitude, as those based on SG-II (Fig. $7 \mathrm{a})$. As a result, the RNA/DNA ratios measured by $\mathrm{EtBr}$ were slightly higher than the ones made with SG-II (Fig. 7b). The slope of the RNA standard curve to the slope of the DNA standard curve was different with each fluorochrome: the $\mathrm{m}_{\mathrm{RNA}} / \mathrm{m}_{\mathrm{DNA}}$ was 0.21 for EtBr and 0.32 for SG-II. The propor- 
tion between these two values (i.e. $0.21 / 0.32=0.66$ ) approaches the regression line of the relationship of the two estimations, as indicated in the legend of Figure $7 b$ (i.e. 0.70571).

This preliminary experiment indicates that SG-II can provide RNA/DNA ratios comparable to those measured with $\mathrm{EtBr}$, although further studies are required. For instance, the comparison between the two fluorochromes should be performed using other organisms; different relationships between the estimations may be obtained when using organisms other than Engraulis encrasicolus larvae. Furthermore, the SG-II and nucleases procedure should be compared with the common EtBr based procedures that perform the "Total" (i.e. RNA+DNA), the "RNase" (DNA) and the "Endogenous" fluorescence assays (e.g. Canino and Caldarone, 1995; Wagner et al., 1998; Rossi-Wongtshowski et al., 2003; Vrede et al., 2002), because the residual fluorescence with EtBr accounts for $<1 \%$ for both RNA and DNA slopes (Caldarone, pers. comm.); here, the comparison was made on the "RNase", "DNase" and "Residual" assays.

\section{CONCLUDING REMARKS}

\section{Accomplishments obtained}

- Coherent RNA/DNA ratios related to the nutritional status of different marine organisms maintained under controlled conditions were obtained using the SG-II and nucleases procedure.

- The comparison between measurements obtained from different experiments can be accomplished by knowing the relationship between the slopes of the RNA and the DNA standard curves used for the calculations. This approach can be used for the comparison between the SG-II and the EtBr based data.

- The sensitivity of the procedure is $40 \mathrm{ng}$ RNA and $10 \mathrm{ng}$ DNA in a $1 \mathrm{ml}$ assay, corresponding to about $400 \mathrm{ng}$ protein or $3 \mu \mathrm{g} \mathrm{DW}$. This high sensitivity of SG-II is a major argument for using it with marine samples characterised by small biomass.

- The method showed adequate levels of linearity, precision and accuracy.

\section{Future research}

- Possible modifications of the extraction procedure regarding the sarcosine and/or EDTA concen- trations when dealing with other types of samples than the one studied here, e.g. copepods, could be made.

- Preservation of the samples and the extracts including the effect of freeze-drying the samples, the comparison of a permanent storage in liquid nitrogen versus a maintenance at $-80^{\circ} \mathrm{C}$ and the maximum period that the extracts can be kept at $-80^{\circ} \mathrm{C}$ should be investigated. Those topics are subjects for investigation not only for the present method, but also for many other biochemical analyses.

- Intercalibration of the SG-II and EtBr methods must take into account both the idiosyncracies of the standards and the idiosyncracies of the two methods.

- Intercalibration between the EtBr based methods and the SYBR Green-nucleases method using different natural samples should be done.

- The boundaries of the variability of the RNA/DNA ratios with different physiological states of cells or organisms should be investigated.

- Exploration of the temporal and spatial variability of the RNA/DNA ratio in the ocean should be undertaken.

\section{ACKNOWLEDGEMENTS}

This study was supported by the European funded project NTAP (EVK3-CT-2000-00022), and by the Spanish Ministry of Science through the FIL (MAR-97 09-02), ARO (MAR-99 12-02) and TURFI (REN2002-01591/MAR) projects. We especially thank Dr. Ted T. Packard for his valuable comments on the manuscript. The suggestions of E.M. Caldarone and other unknown referees markedly improved the final version of the paper. C.R. was funded by the FIL and NTAP projects and the Spanish Ministry of Science and Technology and the European Social Fund. This is ELOISE contribution number 511/40.

\section{REFERENCES}

Arin, M.L., E. Berdalet, C. Marrasé, M. Estrada, N. Guixa and J. Dolan. - 1999. Particulated DNA and protein relative to microorganisms biomass and detritus in the Catalano-Balearic Sea during stratification. J. Plankton Res., 21: 1299-1316.

Barnabé, G. - 1985. L'élévage du loup et de la daurade. In: G. Barnabé and Y. Silbard (eds.), Aquaculture, pp. 627-666. Téchnique et Documentation, Paris, Lavoisier.

Berdalet, E. and Q. Dortch. - 1991. New double-staining technique for RNA and DNA measurement in marine phytoplankton. Mar. Ecol. Progr. Ser., 73: 295-305.

Berdalet, E., M. Latasa and M. Estrada. - 1992. Variations in biochemical parameters of Heterocapsa sp. and Olisthodiscus 
luteus grown on a 12:12 h light:dark cycle. I. Cell cycle and nucleic acid composition. Hydrobiologia, 238: 139-147.

Berdalet, E., C. Roldán, M.P. Olivar and K. Lysnes. - 2005. Quantifying RNA and DNA in planktonic organisms with SG-II and nucleases. Part A. Optimization of the assay. Sci. Mar., 69:

Bergeron, J.P. - 1997. Nucleic acids in ichthyoplankton ecology: a review, with emphasis on recent advances for new perspectives. J. Fish Biol., 51: 284-302.

Bulow, F.J. - 1987. RNA-DNA ratios indicators of growth in fish: A review. In: R.C. and G.E. Hall (eds.), The age and growth of fish, pp. 45-64. The Iowa State University Press, Ames, Iowa.

Caldarone, E.M., M. Wagner, J. St. Onge-Burns and L.J. Buckley. -2001 . Protocol and guide for estimating nucleic acids in larval fish using a fluorescence microplate reader. Northeast Fish. Sci. Cent. Ref. Doc., 01-11: 1-22. http://www.nefsc.nmfs.gov/ nefsc/publications/.

Canino, M.F. and E.M. Caldarone. - 1995. Modification and comparison of two fluorometric techniques for determining nucleic acid contents of fish larvae. Fish. Bull. Us., 93: 158-165.

Clemmesen, C. 1993. - Improvements in the fluorimetric determination of the RNA and DNA content in individual marine fish larvae. Mar. Ecol. Progr. Ser., 100: 177-183.

Fara, A., E. Berdalet and L. Arin. - 1996. Determination of RNA and DNA concentrations in natural plankton samples using thiazole orange in combination with DNase and RNase digestions. J. Phycol., 32: 1074-1083.

Gorokhova, E. and M. Kyle. - 2002. Analysis of nucleic acids in Daphnia: development of methods and ontogenic variations in RNA-DNA content. J. Plankton Res., 24: 511-522.

Guillard, R.R.L. - 1975. Culture of Phytoplankton for Feeding Marine Invertebrates. In: W.L. Smith and M.H. Chanley (eds.), Culture of Marine Invertebrate Animals, pp. 29-60. Plenum Press, New York.

Holm-Hansen, O., W.H. Sutcliffe, Jr. and J. Sharp. - 1968. Measurement of the deoxyribonucleic acid in the ocean and its ecological significance. Limnol. Oceanogr., 13: 507-514.

Mathers, E.M., D.F. Houlihan and L.J. Burren. - 1994. RNA, DNA and protein concentrations in fed and starved herring Clupea harengus larvae. Mar. Ecol. Progr. Ser., 107: 223-231.

Muyzer, G., S. Hottenträger, A. Teske and C. Wawer. - 1996. Denaturing gradient gel electrophoresis of PCR-amplified 16S rDNA - A new molecular approach to analyse the genetic diversity of mixed microbial communities. In: A.D.L. Akkermans, J.D. van Elsas and F.J. de Bruijn (eds.), Molecular Microbial Ecology Manual, Vol. 3.4.4., pp. 1-23. Kluwer Aca- demic Publishers, Netherlands.

Olivar, M.P., P.P. Ambrosio and I.A. Catalán. - 2000. A closed recirculation system for ecological studies in marine fish larvae: growth and survival of sea bass larvae fed with live prey. Aquat. Living Resour., 13: 1-7.

Peters, F., C. Marrase, H. Havskum, F. Rassoulzadegan, J. Dolan, M. Alcaraz and J.M. Gasol. - 2002. Turbulence and the microbial food web: effects on bacterial losses to predation and on community structure. J. Plankton Res., 24: 321-331.

Redfield, A.C., B.H. Ketchum and F.A. Richards. -1963 . The influence of organisms on the composition of sea water. In: M.N. Hill (ed.). The Sea, Vol. 2, pp. 26-77. John Willey, New York.

Regnault, M. and P. Luquet. - 1974. Study by evolution of nucleic acid content of prepuberal growth in the shrimp Crangon vulgaris. Mar. Biol., 25: 291-298.

Roldán, C. - (in progress). Avaluació de l'estat fisiològic de comunitats planctòniques marines mitjançant els quocients RNA/DNA i Proteina/DNA. Noves metodologies, noves perspectives. PhD thesis, Univ. Barcelona.

Rossi-Wongtschowski, C.L.D.B., C. Clemmesen, B. Ueberschär and J. Ferraz Dias. - 2003. Larval condition and growth of Sardinella brasiliensis (Steindachner, 1879): preliminary results from laboratory studies. Sci. Mar., 67: 13-23.

Saiz, E., A. Calbet, A. Fara. and E. Berdalet. - 1998. RNA content of copepods as a tool for determining adult growth rates in the field. Limnol. Oceanogr., 43: 465-470.

Schmidt, D.M. and J.D. Ernst. - 1995. A Fluorometric assay for the quantification of RNA in solution with nanogram sensitivity. Anal. Biochem., 232: 144-146.

Sutcliffe, W.H.J. - 1970. Relationship between growth rate and ribonucleic acid concentration in some invertebrates. J. Fish. Res. Bd. Can. 27: 606-609.

Suthers, I.M. - 1996. Spatial variability of recent otolith growth and RNA indices in pelagic juvenile Diaphus kapalae (Myctophidae): an effect of flow disturbance near an island? Mar. Freshwater Res., 47: 273-282.

Vrede, T., J. Persson and G. Aronsen. - 2002. The influence of food quality (P:C) ratio and somatic growth rate of Daphnia. Limnol. Oceanogr., 47: 487-494.

Wagner, M., E. Durbin. and L. Buckley. - 1998. RNA:DNA ratios as indicators of nutritional condition in the copepod Calanus finmarchicus. Mar. Ecol. Prog. Ser., 162: 173-181.

Scient. ed.: T.T. Packard 